\title{
Myths and Realities: The Academic Viewpoint II
}

\section{Gresham Riley}

Does the college library play a primary role in learning or does it function in a secondary support role to classroom learning? This paper contrasts the myths (false beliefs) and realities of these two points of view. Skills learned in using a college library are highlighted not only as essential to acquiring an education, but also as necessary for lifelong learning.

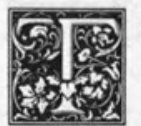

he word myth is clouded in ambiguity. On the one hand, myth can mean a false belief or a belief that, if not false, has no determinable basis in fact. An example would be the belief that it is possible for one of the superpowers to be the winner in a nuclear war. On the other hand, myth can mean a story or fable that, although lacking factual or historical accuracy, nevertheless contains profound insights about the human condition or that of a people or a culture. Myth, in this sense, brings to mind Prometheus, Icarus, or the Garden of Eden. In this paper, I shall use myth as "false belief" and suggest seven such myths.

The first two myth s have to be discussed together because they are mirror images of each other.

Myth \#1: The library is the heart of a college, with classrooms and laboratories serving (to extend our anatomical image) as the brain.

Myth \#2: The classroom and the laboratory are the center of the educational process, with the library functioning in a secondary support role.

Clearly, these two myths are contradictory and would cancel each other if they were not held by different groups: librarians and academic faculty. What are the realities?
Reality \#1: The library is not the heart of a college for many faculty members. Teaching faculty do not view professional librarians as equal partners in the teachinglearning process, but view them as they do residence hall directors, counselors in the career center, or athletic coaches. As scholars, most academic faculty are not predisposed to recognize and to acknowledge a legitimate educational role for the library and for librarians. Faculty members often need to be brought to this recognition and acknowledgment through education. Further, they are more likely to be influenced by local conditions (in particular, the attitude of key college or university administrators toward the role of the library) than by their prior experience or their role as scholars. Finally, many faculty members consider bibliographic instruction as an "add-on" to the basic course work, they consider mastery of the library to be an easy task, and they believe extensive use of the library to be appropriate for only the brightest students. For the majority, the library should serve as a study hall.

Clearly, the library is not the heart of a college if one takes seriously the beliefs and practices of many faculty members. Moreover, the transmission of information, the trial and error of experimentation, and the give and take of ideas in sem- 
inar discussions are all made possible by the classroom and the laboratory. They have to be placed at the heart of the college even if they must share this central spot with other functions.

Reality \#2: It has been argued that the principal objectives of an undergraduate liberal arts and science education are the following:

- Preparation for responsible citizenship in a democratic, pluralistic, and technological society.

- Understanding of and appreciation for the actual and the possible relationships between and among disciplines-in short, the gaining of interdisciplinary insight.

- Development of the ability to think critically and analytically about normative issues.

- Acquisition of skills related to lifelong learning.

Because our formal education in the classroom and the laboratory represents only a small amount of time in the average life span, this last objective (skills related to lifelong learning) is especially important if we are to avoid intellectual and creative stagnation. What are these skills? Among them, certainly, are the following:

- The ability to identify a problem or issue worthy of investigation.

- Knowledge of relevant sources of information that might solve the problem or clarify the issue.

- Possession of criteria that allow one to know when a problem has or has not been solved or when an issue has or has not been clarified.

I believe that the library and the professional librarian have a major and equal role to play in meeting at least one of the objectives of a liberal arts and science education. The obvious basis for this belief is that the mastery of library search strategies is central to those skills that make lifelong learning possible. Consequently, no matter what other functions and other people might be found at the center of the educational process, the library and librarians have a legitimate claim on that space.

If the acquisition of lifelong learning skills is one of the primary objectives of higher education and if the library and li- brarians can play a vital role in the development of these skills, then we can expose three additional myths.

Myth \#3: Extensive use of the library is for only the brightest students; for the rest, it is merely a study hall.

Reality \#3: The reality is that we have failed our students if they graduate without possessing those skills that will allow them to continue to learn once their formal schooling is over. Life expectancy in the United States is seventy-three years. For most of our graduates, this means fiftytwo years during which their minds can continue to be challenged and expanded. Consequently, every student must become familiar with the library as a learning laboratory that can be used throughout life.

Myth \#4: Bibliographic instruction is an "add-on" to the disciplinary content of a course.

Reality \#4: The reality is that knowledge of how to frame a question for investigation and of how to identify and locate relevant resources for answering the question-in short, knowledge about how to solve problems-is as central to academic disciplines as their factual content. Course-centered bibliographic instruction, as a joint effort by both library and instructional faculty, can result in the acquisition by the student of skills in learning how to learn. As such, bibliographic instruction is integrally related to the primary content of every course.

Myth \#5: The teaching faculty in the various academic disciplines are the only educators.

Reality \#5: The mistaken assumption upon which our fifth myth is based is that the classroom exhausts the educational universe. This myth is deeply rooted in the erroneous belief that "education" and "schooling" are the same. Education involves any experience or activity that yields instructive insights about nature, men and women, society, or about the processes by which such insights are gained. Education, in this sense, is virtually coextensive with life. Schooling, on the other hand, involves the orderly transmission and evaluation of formal bodies of knowledge, skills, and values. As such, schooling requires some degree of struc- 
ture, regimen, and discipline-thus, the formal curricula that we have in our colleges and universities.

Once the distinction between education and schooling is acknowledged, it is easy to see that the classroom does not exhaust the educational universe. Furthermore, it becomes clear that librarians are educators no less than are biologists, political scientists, and philosophers. This conclusion is underscored by the fact (which has been demonstrated in the discussion of the previous myth) that bibliographic instruction is integrally related to the primary content of every academic course. Librarians are, indeed, equal partners in the teachinglearning process. This brings us to our final two myths.

Myth \#6: Learning how to use an academic library is an easy task.

Reality \#6: The reality is that learning how to learn is as complex as learning philosophy or chemistry. It should come as no surprise, then, that course-centered bibliographic instruction, if done properly, will be gradated and differentiated. This is to say that specialized bibliographic instruction is needed at different points in a student's educational career. For example, certain resources and certain search strategies are appropriate for general reference work in a freshman composition course; others for an introductory biology course; yet others for an advanced course in genetics; others in a student's major field of study; others for a particular course in a discipline; and still others in interdisciplinary subject areas such as urban studies or women's studies.

Mastery of the library will not result from a tour during student orientation, from viewing a slide-tape production in the learning resources center, or from taking an adjunct course. The issue is simply more serious and more complex than suggested by such responses.

Myth \#7: The library is a well-defined place on campus.

Reality \#7: The reality is that an academic library is less a place than an array of functions and services to be found in many locations. If bibliographic instruction is course-centered (as I believe it should be), then faculty members and professional librarians will be working together for the purpose of determining how best to integrate bibliographic instruction with the other objectives of the course. This means that librarians will be called upon by faculty not only to plan courses but also to evaluate the bibliographies that students use for their research papers. As a result, the library is wherever courses are.

Furthermore, as card catalogs are taken out of boxes and placed in computers, and as lending networks are created through ever-more-sophisticated programs, library search activities will spread across the campus, and the library will become all those places from which documents can be drawn. Even now, but more so in the future, academic libraries will be less substance or a place than function or an activity.

Myths, in the sense of stories that convey profound insights about the human condition, are to be cherished, preserved, and transmitted. Myths, in the sense of false beliefs, are to be exposed. For too long, myths have prevented academic libraries from fulfilling their educational mission within our colleges and universities. The time has come for these myths to be broken. 